\title{
Undergraduate students' pedagogical path: from language learners to professional teachers
}

\section{Estudiantes universitarios de pedagogía: de aprendices de una lengua a profesores profesionales}

\author{
Mauricio Ochoa \\ Marcela Alfonso'
}

\section{Abstract}

This article aims at describing the dynamics Undergraduate Student-teachers and the teaching practice assessors in the English area from the Language Department go through when working together in the teaching practice. We intend to reflect upon student-teachers' transition from their role as learners to their role as professional language educators in the public education setting. We also explore the role of critical reflection, collaborative dialogue and educational research in students' professional growth and the way they conceive education. Finally, we highlight the impact those reflections have had on students and the curriculum in the language program.

\section{Keywords}

Student-teacher, teaching practice, languages, education.

\section{Resumen}

Este artículo pretende describir la dinámica estudiante-maestros y la práctica de enseñanza de asesores en el área de español desde el Departamento de Lenguas trabajar juntos en la práctica docente. Tenemos la intención de reflexionar sobre la transición de estudiantes y profesores de su papel como estudiantes a su papel como profesionales del lenguaje, educadores en la educación pública. También exploramos el papel de la reflexión crítica, el diálogo colaborativo y la investigación educativa de estudiantes profesionales y la manera en la que conciben la educación. Finalmente, subrayamos el impacto de las reflexiones sobre los estudiantes y el currículo en el programa de lenguas.

\section{Palabras clave}

Estudiante-profesor, práctica docente, lenguas, educación.

Artículo recibido el 4 de octubre de 2008 y aprobado el 28 de abril de 2009.

1 Profesores del Departamento de Lenguas de la Universidad Pedagógica Nacional Correos electrónicos: mauricio_ochoa@yahoo.ca-mialfonso@pedagogica.edu.co 


\section{Introduction}

\section{Struggling with own teaching vision vs. the classroom reality}

Before elaborating on the central issue for this article, it is necessary to mention and socialize the origin of our concerns related to language teachers' formative processes and roles in educational settings. As our students, we also went through similar stages in our professional lives, in our experience working at schools there were always concerns about what our role and impact had to be at institutions. Coordinators and head of departments insisted on structural approaches to undertake the language teaching process. This was evident in the type of procedures we were asked to develop in the classroom. They were characterized by an exaggerated emphasis on grammar, vocabulary and memoristic related performances that did not contribute with our students' process in terms of reaching their language learning goals. Due to our desire to truly understand the phenomenon of teaching a foreign language that really fit the different population's needs, we were involved in a professional development practice that permitted us to understand deeply those phenomena presented at different institutions. This professional development was done on the basis of critical reflection upon our own teaching experiences and those of experienced teachers mainly through discussions, analysis of studies done in our country and overseas; and through a systematic research practice about our issues of interest. As a result of this work, the concern about formative processes in foreign language teachers became more relevant when we began to explore the phenomenon related to student-teachers' vision and their social role in education. In that way, our interest to analyze, understand and impact that issue from our daily work with practitioners at Universidad Pedagógica Nacional and other public and private institutions became in our highest priority. In the next pages, a contextualization of the pedagogical practicum at UPN is socialized as well as the elaboration on the reflective-practical process we have been carrying out with student-teachers to help them understand their profession beyond its mere instructional dimension.

The pedagogical research practice at Universidad Pedagógica Nacional takes place mainly at Public Institutions where there are not established English programs because these schools rarely count with especialized English teachers in their teaching staff. Therefore, ninth and tenth semester students become a strong support in the design and execution of the foreign language curriculum for these institutions. Regarding the organization of the teaching practice at the language Department, it is divided in two different stages. First, the Assisted Teaching Practice which occurs in $9^{\text {th }}$ semester where students are familiarized with the institution policies, lesson plan design, English teaching, both in primary and middle school, along with the design of a research proposal that combines two dimensions, language teaching and social issues that emerge from their observations in their different classes. This research becomes their monograph in $10^{\text {th }}$ semester as the requirement for their graduation. The second stage is called the Autonomous Teaching Practice where tenth semester student-teachers continue their pedagogical duties at school and apply their research proposals designed in ninth semester; collect, analyze data and report the findings emerged from their studies to socialize them in the academic community.

As it might be common when facing our first real experience as teachers in a classroom, the $9^{\text {th }}$ semester students, starting their process, reveal an instrumental vision of teaching where the foreign language is understood as a subject to be studied, not as a vehicle to interact, communicate, express oneself and as a way to understand the surrounding context. In this sense, Clavijo (1998) reflects upon how language is seen as an object of instruction rather than as the means to communicate and express thinking in the construction of knowledge. This separation of language and thinking generates situations in the classrooms which become an issue to be considered on teachers' reflection and discourse. In our particular case, this is evident in different instances such as student-teachers' discourse and concerns in the 
different meetings; in their lesson plans when they start by proposing objectives focused on grammar, which result in activities aimed at learning structural concepts; when they measure their students' level of English based on their linguistic knowledge rather than on their performance; when they are amazed and afraid of the "amount of mistakes" students make or because of students' lack of confidence to express their ideas in the foreign language.

Additionally, when students face the reality inside the classrooms dealing with students, the school policies and other dynamics that imply being part of an institution; in contrast with their beliefs about teaching the language, students experience feelings of frustration, uncertainty and powerlessness. As a result they start questioning the process they have gone through at the university along with the knowledge and capacities to teach and handle different situations emerging in the institutions. This can be explained from two perspectives. On the one hand, as Adison (in Johnson, 1996) states, "Most teachers do not have the opportunities to make their beliefs explicit because the institutions in which they work do not generally ask them to articulate their beliefs nor do they place a value on such articulation." This is a common situation in the institutions where the students are doing their teaching practice. On the other hand, Johnson (1996) highlights that most pre service teacher programs work under the assumption that student-teachers are ready to perform their teaching skills achieving effective classroom practices right after they finish their required course work without a better understanding on how these new teachers shape their beliefs and conceptualize these first important experiences and the impact they have on their professional development.

\section{Constructing a critical perspective of teaching through reflection and dialogue}

Based on these observations, we saw the need to start with a process of critical reflection where students instead of judging themselves, their academic background and skills or the school context, they could understand the real role their profession has in our society. Since, we strongly believe that teachers generate genuine changes when they are the product of their transformed beliefs not the answer to imposed actions from external entities. In other words, if teachers transform their pedagogical actions because they are convinced about them, then we can say that they are real transformations and might be more effective than those ones that come from somebody else's orders. Similarly, Richards y Lockhart (1998) explains how teachers assume their role as teachers based on their set of beliefs which are rooted in aspects such as their experience as learners and teachers; and knowledge gained in all the experiences they go through in their professional training. So when teachers are reluctant to change, it is due to the fact that those changes do not match their beliefs. From this, we can infer that before asking teachers to modify their pedagogical practices, it is important to work with them on exploring the reasons of their actions to understand them and generate strategies where they will to enrich their pedagogical actions. Similarly, Dewey (1956) states that whenever people are interested in the discussion of a new movement in education, it is important to take into account the social view, otherwise the expected changes will be perceived as the arbitrary inventions of a group of teachers who are transitory engaged in a momentary pedagogical trend. That is to say, if there is no an in-depth dialogic and reflective process that involves all the members affected by those changes and which ends up in an authentic transformation in our vision about education, the innovative procedures and actions will not transcend the generation of immediate responses to daily situation, leaving aside the opportunity of contributing to the transformation of visions that take the community to their real growth. In that way, the concept of collaborative dialogue as a pedagogical vehicle to understand the foreign language profession from its social dimension cannot be only an interesting idea couple of professors develop at one moment, it has to be a profound feeling and individual belief that is evident not only in the discourse, but also in the daily practice. In other words, if our dialogue with students lacks evident support on our 
actions, there cannot be such thing as an authentic social role evolution. In that sense, we as professors in charge of he pedagogical practicum processes and student-teachers' formation took the responsibility of designing and implementing a methodological dynamic that allows students to access and understand the teaching profession from a reflective ad critical dimension making them able to construct that social role stated before. The following chart illustrates and summarizes the process we followed with our students.
Gráfica 1: Reflective dynamic process.

This strategy consisted on creating an atmosphere of discussion and reflection through group and individual conversations. Student-teachers expressed their fears and doubts; we encouraged them to open their minds by examining their own experience as learners considering the features of their process and the external factors that influenced their learning. We considered those discussions would help them understand language from the social view we acknowledge as relevant to construct beliefs and

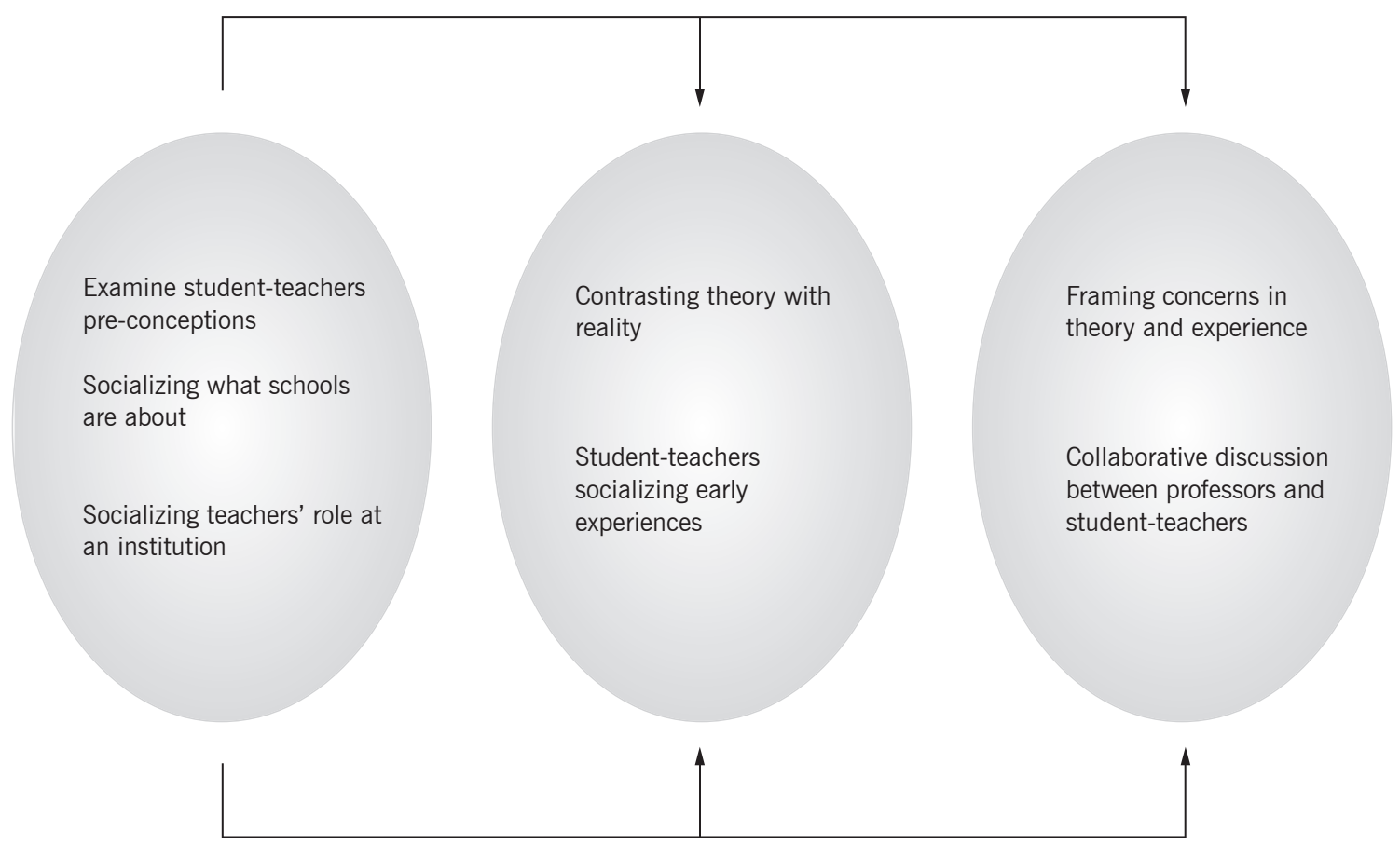

practices beyond the linguistic dimension. As Freire (1976) highlights, the dialogue constitutes the most important moment where reflection and action take place and individuals involved in that dialogue are encouraged to face and understand their reality with the purpose of transforming it by humanizing it. This reflective process was supported by the socialization of our personal experiences both as learner and teachers and updated theory related to pedagogical issues in language teaching. In this process of understanding, reflection was a key element since it gave us the opportunity of opening ourselves free of judgment to analyze our strengths and weaknesses, to share concerns and doubts that usually go with us in this challenging act of teaching. As Alfonso (2004) points out, reflection is the act by which teachers analyze and reconsider their pedagogical actions in the classroom with the purpose of evaluating how effective they are in terms of helping their students reach their learning goals. Consequently, this monitoring act allows teachers to analyze problematic situations from different perspectives in order to generate changes, not only in their teaching practices but also in their context.

In this way, student-teachers were involved in a process which began with a stage of transition where they went beyond criticism and started thinking of alternatives that served two purposes, on the one 
hand, alternatives that aimed at having a positive impact on both, personal relationships with students and in academic aspects. On the other hand, willingness to understand the real role of language teachers in the society, humanizing this way the teaching actions in the classrooms. This matches Ochoa's study (2006), when he finds that when students work cooperatively in an atmosphere where everybody can express their concerns and needs, they see themselves involved in practices where they have to explore their capabilities to discuss issues and solve problems. In this sense, we observed that when student teachers have opportunities to freely bring into our discussion groups those events that puzzled them, was a way to empower themselves to assume their role as teachers who daily have to face situations that demand their knowledge and experience to understand them in order to deal with them properly. In other words, when the student teachers work together not only sharing their concerns but analyzing and reflecting on them instead of receiving an answer given by an expert, they discover that their role as teachers imply an ongoing process of inquiring, reflecting and learning that is founded in their experience and knowledge gained in the interaction with others with the purpose of enriching their vision of teaching so that their practices evolve.

This was evident when students instead of blaming the university and their academic background, they focused their attention on the "problematic situations" observed in the classroom trying to find causes and to what extent they were serious issues to be concerned or simple things that normally occur inside classrooms. They gradually become more sensible in terms of recognizing how their decisions inside the classroom affect their students. This led them to consult with their assessor some of the actions to implement when they were not sure about the impact they might have on the students. This concern is important in the sense that at the beginning of their process their concerns were focused on students' good linguistic and behavioral performance where their role did not go beyond classifying them into good and bad students and where they did not have major responsibility. In other words, the teachers' role was seen as an evaluative role in terms of students' results. On the other hand, as we progressed in our discussions the concern of the student-teachers turned to be on the process of the students and how they could facilitate their learning but not only regarding the language but also their growth as individual and social beings.

In this sense, these students' actions and discourse showed how professionals involved in teachers' education should be aware of the role of dialogue where all the participants feel free to share their ideas and work together to reach common goals. This collaborative dynamic should be favored in order to help educators grow professionally. As Bailey (1996) states, there are two main reasons to promote collaborative dialogue in teacher education. First, learning that emerges from collaborative dialogue is a powerful mechanism for teachers to explore their conceptions of education. The process of exchanging knowledge gained from experience, academic training and other sources is an effective way for teachers to acquire new conceptions of their teaching practices. Second, members are situated in a position where their opinions and experience are valid and mean enrichment for others which by quoting Freire, implies that collaborative dialogue is an invitation for teachers to believe in themselves and their capacity to construct knowledge. This is also supported by Dewey when he points out the nature of the collaborative process at the educative institutions where it emerges as the way members get together and work under common parameters, spirit and aims; according to the author, where there is not a collaborative unit framing a social unit process, it is difficult for a productive activity to appear. In this same fashion, the collaborative dimension included naturally in the professors and student teachers' interaction was a key factor that allowed the group to begin a critical path that helped them to see the language teaching and learning from a different perspective. This process also implied a change not only on practitioners but also on the practicum coordinators who had to go from being the problem solvers to be a peer who collaboratively 
work and analyze the issues at the schools together with his/her students.

\section{Empowering themselves as teachers through their research practice}

At this point, it is important to point out the way this evolving attitude allows student-teachers to reflect upon the school setting and the relation this process has with the formative research they develop in the last two semesters. We notice that as students become more flexible in terms of their vision about teaching, they become more open minded to see themselves as agents of change. In this sense, the process of reflection students go through is relevant in terms of the research process they must undertake to be graduated. Although these two processes occur simultaneously, they develop a more social perspective of research when they have enriched their vision of language teaching as a result of the constant reflections they are part of. This vision fits into what we believe teachers' role need to be focused on, especially, in the type of context we are involved in where the social understanding of our reality prevails over the academic contents. Similarly as Pineda and Clavijo 2003 state "Although the role of both qualitative and quantitative approaches is to explore a given phenomenon, the qualitative approach allows for a richer description and interpretation of a social reality". That is why, the qualitative type of research becomes the alternative for students to explore and understand the educational phenomenon, to improve the instructional dimension of teaching and to empower themselves as teachers-researchers. When they realize that change starts in them and it is evident through the innovations emeged from their research experience. This idea is supported by Hopkins (in Cárdenas and Faustino, 2003), who discusses the nature of a research process where social and anthropological factors are evident. In that type of research, the concerns are focused on the in-depth understanding of a social situation where the procedures to achieve that goal are framed in analytical, descriptive and interpretive performances; In those terms, practitioners have the opportunity to go from a vision focused on immediate results to a more reflective one where they are able to first understand a phenomenon to further think of its solution; most of the times, we agree on the fact that there are not such things as negative evidences miscalled problems but just natural characteristics that we teachers do not understand.

As it was mentioned before, along with the pedagogical evolvement through the reflective perspective given in the teaching practice dynamic, there is a relevant process related not only to their role as teachers but to their role as researchers. In this sense, at the beginning of the process as student-teachers had an instructional conception of teaching, they evidenced the same conception regarding research. On the one hand, research is seen as a non reflective act where the research process means to have an immediate result to solve a linguistic so-called problem. Opposite to what Cárdenas and Faustino (2003) state as the concept of classroom research: the process to answering important questions about situations occurring in the school related to learning, teaching, institutional life or any kind of social relationships members in the community establish.

The student-teachers vision of research was evident when students proposed an implementation focused on improving linguistic issues, expecting positive results in terms of demonstrating that after their implementation the problem would be solved. Then simultaneously, as they started discovering that there are no immediate solutions for classroom dynamics through our frequent discussions, they went through a transformation of paradigm where the understanding of these situations and acknowledging students as individuals who hold differences made them more aware of the way every person constructs their own learning and teachers become facilitators in that construction. In this sense, Stenhouse (in Cárdenas and Faustino, 2003) reflect on classroom research as the alternative to evolve as professionals in education due to the process embedded in it, gives the opportunity to look at teaching within a more reflective and autonomous perspective.

From this awareness, student-teachers reflect on how their role as teachers may affect both positively 
and negatively not only learning processes but also human beings depending on the decisions they make when facing a class. Based on this, students concern about their doing as professionals facing all the challenges that education embraces, they finish their process at the university by analyzing the fact that we are ongoing learners who never have the last answer or ultimate solutions for daily situations in education. Likewise, Cárdenas and Faustino (2003) state that "research is a constant task" a cycle that allows teachers and students to have an impact on their environment and on social and individual situations. "It is life long learning" This is also discussed by Clavijo (2003) by stating that the most relevant factor in the interaction between the individual and his/her context is the opportunity for changes to appear, due to the fact that when the individual is committed to what surrounds him/ her, he/she feels the need to generate actions that may represent a positive impact in his/her setting. This was evident in our students when they began to see themselves, not only as English speakers who happen to teach but as committed teaching professionals who had a social responsibility with the institutions they work at.

This experience has been important for us as teacher educators in the sense that along these two years and a half guiding student-teachers' process we have seen important changes that might be useful for other professionals who are in charged of teachers' education. On the one hand, our constant reflections with our students gave them a voice that informed the university about their needs in terms of the courses they receive. They, for example, concluded that having two semesters of teaching practice was not enough since that was limited time regarding the research projects they proposed. They consider their projects deserve more time due to the impact it might have on the institutions and for the language teachers' community. Taking advantage of the curricular innovation the program was going through; the students' reflections resulted in changes in the curriculum of the program. Now, instead of starting the teaching practice in ninth semester, they will start in eighth semester with the research seminar, so that, they will be able to propose their research process one semester earlier. Likewise, their curriculum suffered another change by implementing a class called "Emphasis on Pedagogical Issues in Language teaching" where seventh semester students reflect upon different issues regarding language teaching and based on those reflections they construct a more informed vision regarding language teaching. In other words, the process of reflection students initiate in ninth semester at the same time they face their teaching practice, starts two semesters before in a formal academic space established by the university with the purpose of discussing pedagogical issues that concern the prospective language teacher so that when they start their teaching practice they undertake it hopefully with a more open minded vision.

Concerning the impact the research teaching practice has had on the students, who already graduated; our students have contacted us to share with us how what they did in their process enabled them to assume challenges in their professional career. One of our students after being for a year an English teacher in another city in Colombia, he was promoted to coordinate the English Department at the school he works for. Another student, due to the interest she gained in research emailed us to let us know how the research process she undertook gave her the possibility of being part of a master program in a recognized university in Bogotá. Likewise, other students have written to let us know how their transformed way of assuming the foreign language teaching has made a difference in the institutions they work for. In that way, from Clavijo's view point, the teacher goes form being an instructor who just transmits a set of contents to a socially engaged person who understands his/her profession from two equally important dimensions. The first one being the expert in everything related to the language he/she is teaching, the pedagogical tools he/she is able to develop with his/her students and the socially skillful individual who is able to orient community processes with the group of people he/ she is part of. In general terms, the teachers see their profession not only as the ones who speak another 
language but as an integral professional who, more than speaking well, needs to develop a set of socio cultural, pedagogical and research skills.

To sum up, this work has been enriching for us in the sense that it is an opportunity to reinforce our beliefs concerning the role of reflection, collaborative dialogue and research as key elements in the process of growing as professionals. The professional growth we have observed in our students is a strong reason to share with professionals involved in teacher education that it is possible to consider a different perspective in language teaching. It is important to insist language teachers that for the sake of our society we cannot continue replicating traditional

\section{Bibliografía}

Alfonso, M. (2004). Collaborative work: english and science teachers sharing their understanding of their teaching practices. Bogotá: Universidad Distrital Francisco José de Caldas.

Bailey, F. (1996). The role of collaborative dialogue in teacher education. En Teacher learning in language teaching. Nueva York: Cambridge University Press.

Cárdenas, R. y Faustino, C. (2003). Developing reflective and investigative skills in teacher preparation programs: the design and implementation of the classroom research component at the foreign language program of Universidad del Valle. Colombian Applied Linguistics Journal.

Clavijo, A. (1998). Redifining the role of curriculum: inquiry based curriculum an alternative. Colombian Applied Linguistics Journal

Clavijo, A. (2000). Formación de maestros. Historia y vida. Reflexión y praxis del maestro colombiano language teaching paradigms that conceive language as the transmission of linguistic knowledge. It is urgent that language teachers understand their social role in helping learners grow as citizens able to transform their realities. Language teachers have the priviledge to contribute with the construction of a better society when allows their students to reflect upon it and inspire them to use their skills and effort to generate new and better alternatives of having a life for them. Language teachers have the opportunity to orient their students to construct a life they feel proud about, but this opportunity is lost if they continue limiting their teaching to the instruction of content.

acerca de la lectura y la escritura. Bogotá: Plaza \& Janés editores.

Dewey, J. (1990). School and society. Child and curriculum. Chicago: University of Chicago Press.

Freire, P. y Macedo, D. (1987). Literacy: reading the word and the world. Boston:

Begin and Harvey.

Johnson, K. (1996). The vision versus the reality: the tensions of the Tesol practicum. En Teacher Learning in language Teaching. Nueva York: Cambridge University Press.

Pineda, C. y Clavijo, A. (2003). Growing together as teacher researchers. Colombian Applied Linguistics Journal.

Richards, J. y Lockhart, C. (1998). Reflective teaching in second language classrooms. Cambridge: Cambridge University Press.

Ochoa, M. (2006). Students expressing themselves through project work. Folios. 